\title{
NEWS
}

\section{Polar bear numbers set to fall}

In a long-anticipated decision hailed as a victory by environmental groups, the United States last week declared the polar bear (Ursus maritimus) a 'threatened' species. But this heightened protection status may have little bearing on the animals' ultimate fate.

The listing, announced by secretary of the interior Dirk Kempthorne on 14 May, connects the continuing retreat in Artic sea ice due to global warming with large potential reductions in the polar-bear population. Last autumn, the US Geological Survey concluded that the animals are likely to lose $42 \%$ of their summer sea ice habitat by mid-century, cutting the world's polar-bear population - estimated at 25,000 - by two-thirds.

Despite this dramatic projection, researchers note that polar bears range across a variety of nations, each with its own conservation approaches, and a variety of habitats, each of which will be affected differently by climate change. Their fates may vary from place to place, too."I don't believe the polar bear will go extinct, but in some areas they will be heavily reduced and may disappear," says veterinary biologist Christian Sonne of the National Environmental Research Institute in Roskilde, Denmark. Factors other than global warming compound stress on the bears, including the accumulation in fat of polychlorinated biphenyls and other pollutants that lower reproductive capacity and weaken the immune system.

Projecting the fate of a creature that ranges over more than $25^{\circ}$ of latitude is difficult. The polar-bear specialist group of the International Union for Conservation of Nature (IUCN) has identified 19 distinct populations that live in markedly different habitats (see map). "Some populations are clearly in far more trouble than others," says biologist Ian Stirling of the Canadian Wildlife Service in Edmonton, Alberta.

For instance, bears that spend the majority of their time on ice may have to migrate long distances to maintain their lifestyle, an additional stress if food is scarce. But polar bear populations in the Canadian archipelago may be fairly stable in the next few decades, as projections suggest that summer sea ice there will be more persistent.

Still others, such as the southernmost populations around Canada's Hudson Bay, may already be experiencing the effects of climate change. Recent studies have shown that such bears are losing valuable hunting time in the spring, when the animals take in most of the year's energy by

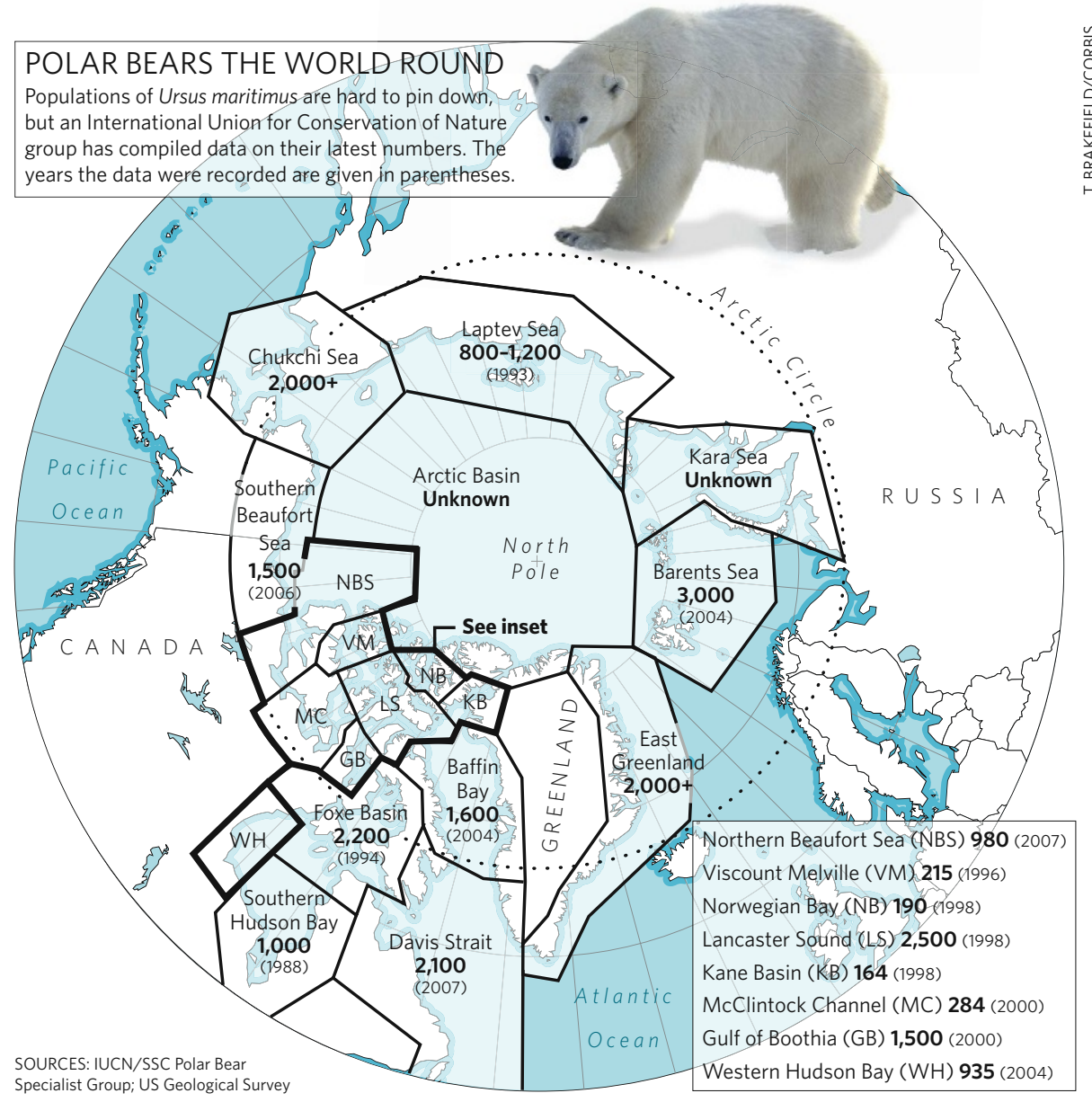

fattening up on nesting ringed seals. West of Hudson Bay, young bears are less likely to survive after earlier sea-ice break-ups, a process which now occurs roughly three weeks earlier than it did 30 years ago ${ }^{1}$. South of the bay, the mass-to-body-length ratio of bears in Ontario has more than halved ${ }^{2}$ since the early 1980 s.

\section{Need to adapt}

Some bear populations may be able to adapt by spending more time on land, but much depends on how quickly the Arctic ice changes.

\section{"Some populations} are clearly in far more trouble than others."
"I think it depends on how fast this happens," says biologist Erik Born of the Greenland Institute of Natural Resources in Nuuk. "Polar bears in some sense are behaviourally flexible, but they are also really specialized to hunt on sea ice."

In the face of sea-ice declines, the best way to manage the bear may be to minimize other threats, Stirling says - to protect denning areas, minimize offshore activities and human traffic, reduce hunting or ensure hunts "move over to bears that are going to die anyway".

That may depend heavily on what circumpolar states do next. The US listing, which was forced by an environmental lawsuit in 2005, places polar bears under the auspices of the powerful Endangered Species Act. But officials wrote the rule in such a way that the 1972 Marine Mammal Protection Act can take precedence. This means that the listing may add no additional limitations to offshore oil and gas drilling. Kempthorne also argued that the new listing could not be used to regulate greenhouse-gas emissions.

No circumpolar state regulates greenhousegas emissions specifically to protect the polar bear. Norway, which has had the strongest protections, upgraded the bear's status to 'vulnerable' on its Red List of imperilled species after the IUCN did the same in 2006. But "that doesn't change anything," says Dag Vongraven of the Norwegian Polar Institute in Tromsø. 
Norway's outright ban on hunting is the only regulatory structure to protect polar bears in that country, he says.

The United States, Greenland (under home rule from Denmark) and Canada permit limited hunting. Russia has outlawed polar bear hunts, but illegal kills are thought to be common, says Vongraven.

Canada is also considering whether to upgrade the polar bear's status. Last month, a government advisory committee announced that it would not recommend raising the bear's status to 'threatened' from 'species of concern', a move that could impact hunting activities. A decision will be made after August, when the group's final recommendations are sent to environment minister John Baird.

\section{Legal battles}

In the United States, the new listing is likely to be challenged. "There will clearly be a series of lawsuits over this that will take a long time to resolve," says Holly Doremus, an environmental lawyer at the University of California, Davis. In particular, she says, exempting federal agencies from consulting with the Fish and Wildlife Service on projects involving greenhouse-gas emissions is unlikely to withstand judicial review. "I think the Bush administration is just trying to kick this to the next administration because they don't know how to deal with it," she says.

In the meantime, prompted by other environmental lawsuits, the Fish and Wildlife Service is considering adding other species - including the emperor penguin - to the endangered or threatened species lists, partly because of threats from climate change.

And polar bears are likely to remain at the top of the international agenda for the foreseeable future. "Certainly the polar bear has become that iconic figure that will hopefully become the rallying point for that kind of discussion to take place," says Lyle Laverty, assistant secretary for Fish, Wildlife and Parks.

Next year, officials in the bear's range states plan to meet in Tromsø, Norway, to discuss management options. It will be the first such meeting in 28 years.

Rachel Courtland

\footnotetext{
1. Regehr, E. V., Lunn, N. J., Amstrup, S. C. \& Stirling, I. J. Wildl. Mgmt 71, 2673-2683 (2007).

2. Obbard, M. E. et al. Temporal Trends in the Body Condition of Southern Hudson Bay Polar Bears Climate Change Research Information Note Number 3, Ontario Ministry of Natural Resources (2006).
}

See Editorial, page 427.

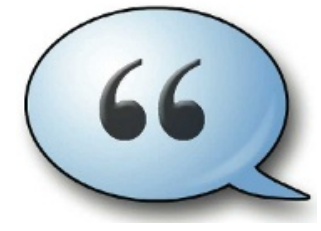

HAVE YOUR SAY

Comment on any of our news stories, online. www.nature.com/news

\section{Whales are on the rise}

Humpback whale numbers in the northern Pacific Ocean have ballooned to nearly 20,000 , the largest population seen since the majestic mammals were hunted nearly to extinction half a century ago.

The number of humpbacks hit an all-time low of 1,400 or even lower by 1966 , when their hunting was banned internationally. The new census, from one of the largest whale studies ever undertaken, shows that the animals have rebounded much better than expected.

"We had no idea the population could have grown this high," says John Calambokidis, a biologist at Cascadia Research Collective, a non-profit environmental research institute in Olympia, Washington, and a principal investigator on the study.

But cetologists are concerned about the estimated 900 humpbacks that migrate to the western Pacific. This subpopulation may be being hunted illegally, with some getting entangled in the nets of fishermen. Still, researchers say that the western Pacific population is increasing at more than $6 \%$ per year - roughly the same rate as humpbacks in other regions.

The three-year study, called SPLASH (Structure of Populations, Levels of Abundance and Status of Humpbacks), involved more than 400 researchers from 10 nations. Its US\$3.7-million price tag was paid for with funding from the US National Oceanic and Atmospheric Administration (NOAA), the Canadian government and private sources. It used everything from ocean-going research ships to motorized outrigger canoes to identify whales by their fluke markings, then monitor them from their feeding grounds off Canada and the Aleutian Islands to their winter and breeding grounds off Hawaii, Latin America and Asia.

"This is a great candidate to show the success of conservation programmes," says
Jay Barlow, a marine mammalogist with the NOAA Southwest Fisheries Science Center in La Jolla, California, and a study leader. The project was conceived in 2002 when US laws such as the Endangered Species Act and the Marine Mammal Protection Act were under attack by Republicans in Congress.

The report's findings may open a new dialogue about the study and regulation of humpbacks under the auspices of the International Whaling Commission. And there will probably be talks about re-evaluating the humpback's current classification as endangered.

Barlow says that revising the protection status to 'threatened' may be reasonable for the eastern-Pacific population, but that western-Pacific whales should remain listed as 'endangered'. "This study will open a discussion, which will be a long one," he says.

Japan continues 'scientific whaling' attempts on a separate population of humpbacks in the southern Pacific. Last year, the country had planned to kill nearly 1,000 humpback, fin and minke whales in the area, but international pressure reduced the take to about 550 minkes.

SPLASH also intends to furnish details about the humpback population structure, including the animals' loyalty to certain feeding or breeding regions and how this affects their survival.

Almost 8,000 humpbacks were individually catalogued, with tissue samples taken from more than 6,000 of these for DNA analysis. Already, SPLASH has revealed the existence of an unknown wintering and breeding ground - a refuge that researchers haven't yet located, but is probably in the middle of the Pacific Ocean. DNA records may play an important part in locating the area. "Finding that will be a fun project," says Barlow. Rex Dalton

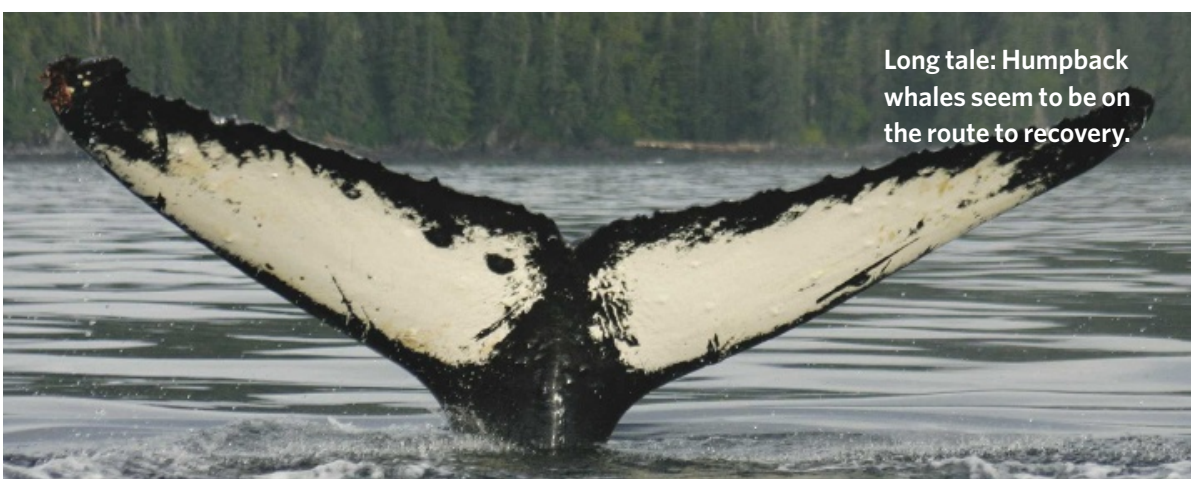

